\title{
Antibodies specific for measles virus envelope antigens and autoantibodies in patients with chronic active hepatitis
}

\author{
PV SHIRODARIA, ${ }^{*}$ SA MCMILLAN, $\dagger$ ME CALLENDER, $\ddagger$ MARGARET HAIRE,${ }^{*} \dagger$ \\ ELIZABETH FLEMING,${ }^{*}$ JD MERRETT,§ TT FULTON
}

From the *Department of Microbiology and Immunobiology, The Queen's University of Belfast, the $\dagger$ Immunology Laboratory, Belfast City Hospital, the $¥$ Royal Victoria Hospital, Belfast, and the §Department of Medical Statistics, The Queen's University of Belfast, Northern Ireland.

SUMMARY Distinctly increased levels of antibodies to measles virus envelope antigens haemolysin and haemagglutinin were found in the sera of patients with chronic active hepatitis compared with a normal control group, using immunofluorescence and functional tests. Similarly, a higher incidence of smooth muscle antibody of both IgG and IgM classes was observed in the patients and an important correlation was found between haemolysin antibodies specific for measles virus and smooth muscle antibody of IgG and IgM classes. In contrast, there was no such correlation between the virus specific haemolysin antibodies and antinuclear antibodies. The increased levels of antibodies to measles virus envelope antigens and of autoantibodies may reflect defects in immunoregulation rather than persistent infection with measles virus.

Increased antibody titres to measles virus have often been observed in the sera of patients with chronic active hepatitis who are negative for hepatitis B surface antigen (HBs Ag).$^{1-7}$ Similarly, a higher incidence of autoantibodies, especially smooth muscle antibodies and antinuclear antibodies, has also been detected in the sera of these patients. ${ }^{8-10}$

Measles virus, a member of the genus moribillivirus of the family Paramyxoviridae, both haemagglutinates and haemolyses rhesus monkey erthrocytes but lacks neuraminidase. ${ }^{11}$ Biological and biochemical analyses of measles virus have shown that the two antigens located on the surface of the virus envelope are haemagglutinin and haemolysin, while the major antigen, nucleocapsid, is held internally within the virion. In addition, both haemagglutinin and haemolysin are expressed on the membrane of cells infected with measles virus, and nucleocapsid is located intracellularly..$^{12-15}$ Antibodies against haemagglutinin and haemolysin can be identified separately by the functional tests haemagglutination inhibition and haemolysin inhibition. In contrast, the complement fixation test measures the bulk of the antibody to nucleocapsid, apart from a

Accepted for publication 31 July 1985 small proportion of antibody that may be against haemagglutinin..$^{12} 16^{17}$ Furthermore, we have shown that measles virus haemolysin is sensitive to acetone and that measles virus haemagglutinin is resistant to acetone, and these differences in the sensitivity of the two antigens can be used to measure antibodies to haemolysin and haemagglutinin antigens in the fluorescence antibody test..$^{1519}$ Moreover, in the sera of normal healthy subjects the titres of haemolysin antibodies are always higher than those of haemagglutinin antibodies. ${ }^{16}$ Therefore, fluorescence antibody titres obtained by staining the membrane of unfixed cells infected with measles virus represent mostly antibodies to haemolysin and the titres obtained by staining the membrane of acetone fixed cells infected with measles virus represent haemagglutinin antibodies. Similarly, the staining of intracellular inclusions in acetone fixed cells represents antibodies to nucleocapsid. 151819

Although both complement fixation and haemagglutination inhibition tests have been used to estimate antibodies specific for measles virus in the sera of patients with chronic active hepatitis, haemolysin inhibition antibodies have not been measured. These antibodies are neutralising ${ }^{16-18}$ and are therefore important in protection against measles infection $^{20}$; they are also found to be in excess of 
haemagglutination inhibition antibodies in healthy immune subjects after primary childhood measles. ${ }^{16}{ }^{18}$ In this study we therefore investigated levels of haemolysin and haemagglutinin antibodies specific for measles virus in the sera of a group of patients with chronic active hepatitis using fluorescence antibody and functional tests. We also examined titres of autoantibodies to determine whether there was a correlation between autoantibodies and the viral antibodies.

\section{Material and methods}

\section{PATIENTS AND CONTROLS}

Serum samples were obtained from 16 patients with chronic active hepatitis negative for $\mathrm{HBs} \mathrm{Ag}$. The patients comprised 13 women and three men (mean age 47.7 years; range $27-74$ years). The diagnosis was based on the clinical criteria specified by the Fogerty International Centre, 1976, ${ }^{21}$ and on histological criteria described by an international group $^{22}$ for liver biopsy. At the time of the study seven patients had increased serum aspartate aminotransferase and serum alanine aminotransferase activities (range 60-200 U/l) and nine patients had normal activities (10-45 U/l). All the patients also had increased $\gamma$-globulin values. In five cases a second serum sample was obtained after about 11-22 months. Sera were collected over three years and stored at $-20^{\circ} \mathrm{C}$ until tested. All patients were receiving either prednisolone or adrenocorticotrophic hormone, and seven patients were receiving azathioprine in addition,

Control sera were obtained from 16 healthy blood donors (mean age 47.5 years; range $26-74$ years). The sera were matched for sex and age within two years.

\section{CELLS AND VIRUS}

HEp-2 cell line was obtained from Gibco-Biocult Ltd, and cells were propagated in Eagle's minimal essential medium supplemented with $10 \%$ fetal bovine serum and $10 \%$ tryptose phosphate broth.

The stock of the Edmonston strain of measles virus adapted to HEp-2 cells was prepared as described previously. ${ }^{23}$ Infectivity of the stock pool of virus was measured by plaque assay ${ }^{23}$; the titre was $1 \times 10^{7}$ plaque forming units $/ \mathrm{ml}$.

HAEMAGGLUTININ AND HAEMOLYSIN ANTIGENS Extracellular measles virus was used to prepare both haemagglutinin and haemolysin antigens. Monolayers of HEp- 2 cells were infected at a multiplicity of infection of 0.01 plaque forming units/cell. Five days after infection, when $90 \%$ of the cells showed extensive cytopathic effect, the medium was removed and clarified by centrifugation at $1700 \mathrm{~g}$ for 10 minutes. The supernatant was further concentrated by centrifugation at $73000 \mathrm{~g}$ for two hours at $4^{\circ} \mathrm{C}$, and the pellet was resuspended in $0.01 \mathrm{M}$ phosphate buffered saline in 1/50 of the original volume.

The haemagglutinin test was carried out in Flow microtitre plates. Serial two fold dilutions $(0.025 \mathrm{ml})$ of the preparation were made in Dulbecco's phosphate buffered saline ( $\mathrm{pH} 7 \cdot 4)$, and equal volumes of $1 \%$ washed rhesus monkey erthrocytes were added. After incubation at $37^{\circ} \mathrm{C}$ for one hour the titre of the haemagglutinin was estimated as the reciprocal of the highest dilution that produced complete haemagglutination.

The haemolysin test was carried out in three $x$ half inch plastic tubes. Serial two fold dilutions $(0.25 \mathrm{ml})$ of the preparation were made in Dul-

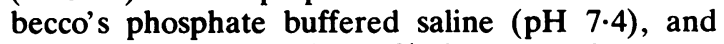
equal volumes of washed $2 \%$ rhesus monkey erythrocytes were added. After incubation at $37^{\circ} \mathrm{C}$ for 18 hours the samples were centrifuged at $200 \mathrm{~g}$ for five minutes and the supernatants examined for haemolysis. The reciprocal of the highest dilution that produced complete lysis was taken as the titre of the haemolysin preparation.

The preparations used in the serological tests had haemagglutinin and haemolysin titres of 1024 and 512 , respectively, and single preparations of each antigen were used throughout the study.

\section{SEROLOGICAL METHODS FOR DETECTING ANTIBODIES AND AUTOANTIBODIES SPECIFIC FOR MEASLES VIRUS}

To avoid non-specific reactions in the indirect fluorescence antibody method and functional haemagglutination inhibition and haemolysin inhibition tests each serum diluted $1 / 10$ in phosphate buffered saline was first absorbed overnight at $4^{\circ} \mathrm{C}$ with washed, pelleted HEp- 2 cells treated with acetone $(30 \% \mathrm{v} / \mathrm{v})$. After clarifying by centrifugation at $10000 \mathrm{~g}$ for 20 minutes each serum was further absorbed for one hour at $37^{\circ} \mathrm{C}$ with washed rhesus monkey erythrocytes (obtained from rhesus monkeys kept in the animal house of the Queen's University of Belfast) in a final concentration of $10 \%$. The sera were further clarified by centrifugation at $200 \mathrm{~g}$ for 10 minutes before use. The fluorescein isothiocyanate (FITC) conjugated sheep antihuman IgG and FITC conjugated sheep antihuman IgM (Wellcome Diagnostics Ltd, Beckenham, England) used in this study were absorbed with HEp- 2 cells treated with acetone as described above. The optimal dilutions of each conjugate were further determined by titration in indirect immunofluorescence tests on cells infected with measles virus, using an 
early serum from a patient suffering from the infection. The FITC conjugated sheep antihuman IgG was used at a dilution of 1/60 and the FITC conjugated antihuman $\operatorname{IgM}$ at a dilution of $1 / 30$. Only specific staining of cells infected with the virus was observed. The staining of either uninfected or infected cells was not observed with conjugates on their own.

Immunofuorescence Semiconfluent monolayers of HEp- 2 cells were grown on $13 \mathrm{~mm}$ round coverslips in $5 \mathrm{~cm}$ petri dishes $\left(2 \times 10^{5}\right.$ cells per dish $)$ in Eagle's growth medium at $37^{\circ} \mathrm{C}$ for 18 hours in $5 \%$ carbon dioxide. The cells were washed once with Eagle's medium without serum and infected at a multiplicity of 0.01 plaque forming units/cell. After adsorption at $37^{\circ} \mathrm{C}$ for one hour $4 \mathrm{ml}$ of maintenance medium was added and the dishes were incubated for 48 hours at $37^{\circ} \mathrm{C}$ to give about $30 \%$ infected cells. The coverslips were either used unfixed or were fixed in acetone for eight minutes at room temperature after three washes in phosphate buffered saline and one rinse in fresh acetone. The fixed coverslips were air dried for one hour before use or were stored at $-20^{\circ} \mathrm{C}$ before use. The percentage of infected cells in each preparation was routinely confirmed using FITC conjugated monkey antimeasles serum in the direct immunofluorescence test as described previously. ${ }^{24}$ The advantage of using this method was that the staining of infected cells could easily be differentiated from that of uninfected cells in the same preparation.

To detect antibodies to measles virus haemolysin serial two fold dilutions of sera in phosphate buffered saline were applied to unfixed coverslip preparations of infected cells that had been rinsed rapidly three times in phosphate buffered saline for 45 minutes at $37^{\circ} \mathrm{C}$. After three more quick rinses in phosphate buffered saline FITC conjugated sheep antihuman IgG was applied for 45 minutes at $37^{\circ} \mathrm{C}$. After thorough rinsing in phosphate buffered saline the coverslips were mounted in glycerol saline and examined under a fluorescence microscope. The procedure used to detect antibodies to haemagglutinin (including nucleocapsid) was similar to that described for the unfixed preparation, except that instead of quick rinses in phosphate buffered saline the coverslips were washed for 15 minutes in phosphate buffered saline. The fluorescence antibody titre was the highest dilution of the serum that gave specific staining of the membrane of the infected cells for haemolysin antibody and staining of the membrane of the infected acetone fixed cells for haemagglutinin antibody and staining of viral inclusions for nucleocapsid antibody.

Haemagglutination inhibition Serial two fold dilutions of serum were prepared in Dulbecco's phos- phate buffered saline ( $\mathrm{pH} \mathrm{7.4)} \mathrm{in} 0.025 \mathrm{ml}$ volumes in microtitre plates and mixed with a preparation of haemagglutinin containing four haemagglutinating doses. After incubation at $37^{\circ} \mathrm{C}$ for one hour an equal volume of washed $1 \%$ suspension of rhesus monkey erythrocytes was added. The erythrocytes were allowed to settle at $37^{\circ} \mathrm{C}$ for one hour. The highest dilution of serum giving $50 \%$ inhibition of agglutination was taken as the titre of the antibody.

Haemolysin inhibition Serial two fold dilutions of serum were prepared in Dulbecco's phosphate buffered saline ( $\mathrm{pH} 7.4)$ in $0.25 \mathrm{ml}$ volumes in three $\times$ half inch plastic tubes and mixed with a preparation of haemolysin containing eight haemolysing doses. After incubation at $37^{\circ} \mathrm{C}$ for one hour an equal volume of $2 \%$ washed suspension of rhesus monkey erythrocytes was added. After further incubation at $37^{\circ} \mathrm{C}$ for 18 hours the cells were centrifuged at $200 \mathrm{~g}$ for five minutes and the supernatants examined for lysis. The highest dilution of serum giving $50 \%$ reduction of haemolysis was taken as the titre of the antibody.

Autoantibodies Unfixed $5 \mu \mathrm{m}$ cryostat sections of. rat liver, kidney, and stomach snap frozen as a composite block with carbon dioxide were used as substrate to detect and estimate smooth muscle antibody, antinuclear antibodies, and antimitochondrial antibodies in IgG and IgM classes. Serial two fold dilutions of sera in phosphate buffered saline were applied to the tissue sections for $\mathbf{3 0}$ minutes at room temperature, washed for 45 minutes in phosphate buffered saline and then treated for a further 30 minutes with either FITC conjugated sheep antihuman IgG or FITC conjugated sheep antihuman IgM. After washing for 45 minutes the sections were mounted in glycerol saline and examined under a fluorescence microscope. The titres of autoantibodies were determined according to the criteria described previously. ${ }^{25}$

\section{ADSORPTION OF SERA WITH SMOOTH MUSCLE TISSUE}

A homogenate of smooth muscle tissue was prepared by washing a surgical specimen of human uterus in phosphate buffered saline to remove blood. Four sera from patients with chronic active hepatitis diluted $1 / 5$ were absorbed twice with the homogenate $(30 \% \mathrm{v} / \mathrm{v})$ overnight at $4^{\circ} \mathrm{C}$ and were clarified by centrifugation at $10000 \mathrm{~g}$ for 15 minutes. The sera were tested by immunofluorescence, in parallel with aliquots of the same specimens unabsorbed for virus specific IgG class of antibody against unfixed antigens, acetone fixed antigens, and autoantibodies in IgG and IgM classes. 
Table 1 Geometric mean titres and mean logarithmic titres of antibodies specific for measles virus by immunofuorescence and functional tests

\begin{tabular}{|c|c|c|c|c|}
\hline \multirow[t]{3}{*}{ Study group } & \multicolumn{4}{|c|}{ Titre of virus specific antibodies } \\
\hline & \multicolumn{2}{|c|}{ Immunoftuorescence tests (IgG antibody) } & \multicolumn{2}{|l|}{ Functional tests } \\
\hline & $\begin{array}{l}\text { Unfixed membrane } \\
\text { antigens (haemolysin) }\end{array}$ & $\begin{array}{l}\text { Acetone fuxed intracellular } \\
\text { antigens (haemagglutinin } \\
\text { plus nucleocapsid) }\end{array}$ & Haemolysin inhibition & $\begin{array}{l}\text { Haemagglutination } \\
\text { inhibition }\end{array}$ \\
\hline $\begin{array}{l}\text { Chronic active hepatitis }(n=16) \text { : } \\
\text { Geometric mean titre }{ }^{*} \\
\text { Mean (SD) logarithmic titre }\end{array}$ & $3125^{*}$ & $\begin{array}{l}415 \\
2.618(0.514)\end{array}$ & $\begin{array}{l}1280 \\
3 \cdot 107(0 \cdot 440)\end{array}$ & $\begin{array}{l}247 \\
2.392(0.559)\end{array}$ \\
\hline $\begin{array}{l}\text { Blood donors }(\mathrm{n}=16): \\
\text { Geometric mean titre } \\
\text { Mean }(\mathrm{SD}) \text { logarithmic titre } \\
\text { Probability }\end{array}$ & $\begin{array}{l}190 \\
2 \cdot 279(0 \cdot 356) \\
0 \cdot 001\end{array}$ & $\begin{array}{l}73 \\
1.865(0.308) \\
0.0007\end{array}$ & $\begin{array}{l}199 \\
2 \cdot 298(0 \cdot 325) \\
0.0010\end{array}$ & $\begin{array}{l}44 \\
1 \cdot 640(0.379) \\
0.0015\end{array}$ \\
\hline
\end{tabular}

*Expressed as reciprocals of serum dilutions.

tObtained by Wilcoxon matched pairs signed rank test.

\section{STATISTICAL ANALYSIS}

The comparison of the virus specific antibody titres in the chronic active hepatitis and control sera were made by the Wilcoxon matched pairs and the signed rank test. The incidence of smooth muscle antibody of IgG class in sera from patients with chronic active hepatitis and controls was evaluated using McNemar's test, and the binomial test was used for comparing the incidence of smooth muscle antibody of IgM class and antinuclear antibodies of IgG and IgM classes in diseased and normal sera. Spearman's rank correlation coefficients were used to test correlations between measles virus specific antibodies to haemolysin (unfixed immunofluorescence) and smooth muscle antibody of IgG class, antinuclear antibodies of IgG class, aspartate aminotransferase, alanine aminotransferase, and immunoglobulin concentrations in sera of patients with chronic active hepatitis. For comparison of virus specific haemolysin antibody titres (unfixed immunofluorescence) in patients' sera positive for antinuclear antibodies and negative for antinuclear antibodies the Wilcoxon rank sum test was used. The conventional level of significance $(p<0.05)$ was used throughout.

\section{Results}

\section{VIRUS SPECIFIC ANTIBODIES}

Table 1 shows the geometric mean titres and mean logarithmic titres of measles virus specific antibodies against haemolysin (unfixed) and haemagglutinin

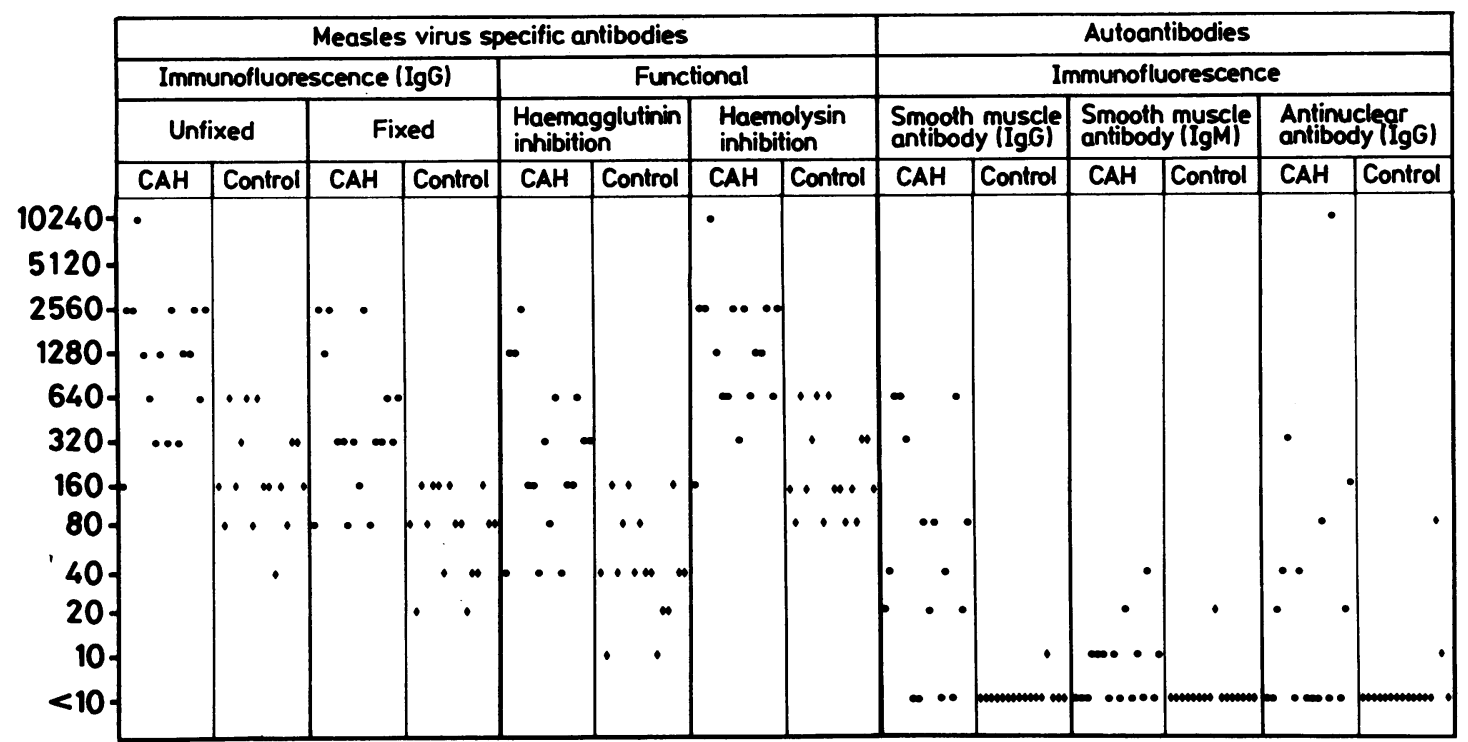

Fig. 1 Reciprocal titres of antibodies specific for measles virus and autoantibodies in 16 patients with chronic active hepatitis (CAH) and 16 controls matched for age and sex. 
Table 2 Incidence of IgG and IgM class autoantibodies in patients' and control sera. (Values are numbers (\%) of subjects.)

\begin{tabular}{|c|c|c|c|c|c|c|}
\hline \multirow[t]{3}{*}{ Study group } & \multicolumn{6}{|c|}{ Immunofuorescence tests } \\
\hline & \multicolumn{3}{|c|}{ IgG class of antibody } & \multicolumn{3}{|c|}{ IgM class of antibody } \\
\hline & $\begin{array}{l}\text { Smooth muscle } \\
\text { antibody }\end{array}$ & $\begin{array}{l}\text { Antinuclear } \\
\text { antibodies }\end{array}$ & $\begin{array}{l}\text { Antimitochondrial } \\
\text { antibodies }\end{array}$ & $\begin{array}{l}\text { Smooth muscle } \\
\text { antibody }\end{array}$ & $\begin{array}{l}\text { Antinuclear } \\
\text { antibodies }\end{array}$ & $\begin{array}{l}\text { Antimitochondrial } \\
\text { antibodies }\end{array}$ \\
\hline $\begin{array}{l}\text { Chronic active hepatitis }(n=16) \\
\text { Blood donors }(n=16)\end{array}$ & $\begin{array}{c}12(75) \\
1(6)\end{array}$ & $\begin{array}{l}8(50) \\
2(13)\end{array}$ & $3(19)$ & $\begin{array}{l}8(50) \\
1(6)\end{array}$ & $\begin{array}{l}4(25) \\
3(19)\end{array}$ & 3 (19) \\
\hline
\end{tabular}

(including nucleocapsid) as measured by immunofluorescence and functional tests of inhibition of haemagglutinin and haemolysin. Fig. 1 shows the individual titres of antibodies. The patients with chronic active hepatitis had higher titres of virus specific antibodies as measured by immunofluorescence and functional tests than the normal controls (Table 1). Notably, virus specific IgG antibody against haemolysin by immunofluorescence and haemolysin inhibition tests showed the highest titres. A significant correlation was also found between the virus specific fluorescence antibody test against haemolysin (unfixed) and functional haemolysin inhibition antibody test $\left(r_{s}=0.96, p=\right.$ 0.001 ). Similarly, highly significant correlations were found between virus specific IgG antibody against haemolysin (unfixed) by immunofluorescence and haemagglutinin including nucleocapsid (acetone fixed) by immunofluorescence $\left(r_{s}=0.92, p\right.$ $=0.001)$.

\section{AUTOANTIBODIES}

Table 2 shows the incidence of IgG and IgM classes of smooth muscle antibody, antinuclear antibodies, and antimitochondrial antibodies. Fig. 1 gives the individual titres of these antibodies. A significantly higher incidence of smooth muscle antibody of $\mathrm{IgG}$ class $\left(\chi^{2}=7.78 ; \mathrm{df}=1 ; 0.01>p>0.001\right)$ and smooth muscle antibody of $\operatorname{IgM}$ class $(p=0.04)$ was found in the patients' sera, and the titre of smooth muscle antibody was higher in the IgG class than in the IgM class. Although the incidence of antinuclear antibodies of IgG class was greater in patients' sera, the difference was not significant $(p=0.07)$. This may have been due to the small number of patients in the study group. No difference was observed in the incidence of antinuclear antibodies of IgM class between the patient and control groups. Antimitochondrial antibodies of IgG and IgM classes were found only in a small number of patients' sera and not in control sera (Table 2).

\section{VIRUS SPECIFIC ANTIBODIES AND}

AUTOANTIBODIES IN DUPLICATE SERA

Table 3 shows the comparison of the virus specific antibodies and autoantibodies in the duplicate sera obtained from five patients after 11-24 months. The results indicated that both the virus specific antibodies and the autoantibodies fluctuated, but as the number of patients was small statistical analysis was not carried out.

\section{CORRELATION BETWEEN VIRUS SPECIFIC}

\section{ANTIBODIES AND AUTOANTIBODIES}

In patients with chronic active hepatitis a highly significant correlation was observed between virus specific haemolysin antibody (unfixed) and smooth muscle antibody of $I g G$ class $\left(r_{s}=0.78, p=0.001\right.$; Fig. 2), whereas the correlation with smooth muscle antibody of IgM class was less significant $\left(r_{s}=0.54\right.$, $p=0.03$ ). A significant correlation was not found between virus specific haemolysin antibody and

Table 3 Comparison of titres* of antibodies specific for measles virus and autoantibodies in duplicate serum samples obtained from five patients

\begin{tabular}{|c|c|c|c|c|c|c|c|c|}
\hline \multirow{2}{*}{$\begin{array}{l}\text { Case } \\
\text { No }\end{array}$} & \multirow{2}{*}{$\begin{array}{l}\text { Interval between } \\
\text { samples (months) }\end{array}$} & \multirow[t]{2}{*}{ Sample } & \multicolumn{2}{|c|}{ Fluorescence antibody IgG class } & \multicolumn{2}{|c|}{ Functional antibody } & \multicolumn{2}{|c|}{ Autoantibodies IgG class } \\
\hline & & & $\begin{array}{l}\text { Unfixed } \\
\text { antigens }\end{array}$ & $\begin{array}{l}\text { Acetone fixed } \\
\text { antigens }\end{array}$ & $\begin{array}{l}\text { Haemolysin } \\
\text { inhibition }\end{array}$ & $\begin{array}{l}\text { Haemagglutination } \\
\text { inhibition }\end{array}$ & $\begin{array}{l}\text { Smooth muscle } \\
\text { antibody }\end{array}$ & $\begin{array}{l}\text { Antimuclear } \\
\text { antibodies }\end{array}$ \\
\hline 1 & 11 & \multirow{8}{*}{$\begin{array}{l}\text { \{ First } \\
\text { Second } \\
\text { \{ First } \\
\text { Second } \\
\text { \{ First } \\
\text { Second } \\
\text { \{ First } \\
\text { Second } \\
\text { \{ First } \\
\text { Second }\end{array}$} & \multirow{8}{*}{$\begin{array}{r}2560 \\
1280 \\
160 \\
320 \\
1280 \\
320 \\
160 \\
320 \\
2560 \\
2560\end{array}$} & \multirow{8}{*}{$\begin{array}{r}1280 \\
640 \\
40 \\
80 \\
320 \\
160 \\
40 \\
80 \\
2560 \\
1280\end{array}$} & \multirow{8}{*}{$\begin{array}{r}2560 \\
1280 \\
160 \\
640 \\
1280 \\
320 \\
160 \\
640 \\
2560 \\
2560\end{array}$} & \multirow{8}{*}{$\begin{array}{r}1280 \\
320 \\
20 \\
40 \\
160 \\
80 \\
20 \\
40 \\
640 \\
640\end{array}$} & \multirow{8}{*}{$\begin{array}{r}640 \\
40 \\
<10 \\
<10 \\
<10 \\
20 \\
40 \\
<10 \\
<10 \\
80\end{array}$} & \multirow{8}{*}{$\begin{array}{r}20 \\
<10 \\
<10 \\
<10 \\
<10 \\
<10 \\
<10 \\
<10 \\
<10 \\
<10\end{array}$} \\
\hline & 11 & & & & & & & \\
\hline 2 & 11 & & & & & & & \\
\hline & & & & & & & & \\
\hline 3 & 22 & & & & & & & \\
\hline 4 & 18 & & & & & & & \\
\hline & & & & & & & & \\
\hline 5 & 11 & & & & & & & \\
\hline
\end{tabular}

*Expressed as reciprocals of serum dilutions. 


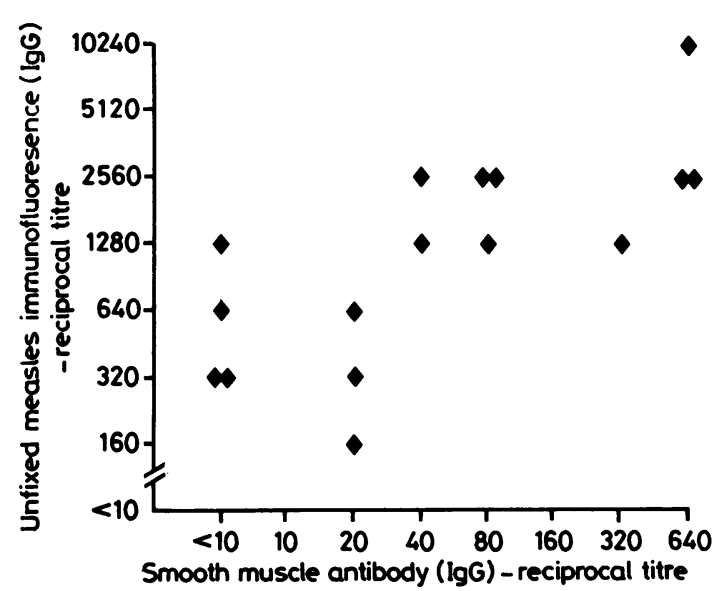

Fig. 2 Correlation between titres (unfixed immunofuorescence) of haemolysin antibody specific for measles virus and smooth muscle antibody titres in 16 patients with chronic active hepatitis $\left(r_{s}=0.78\right)$.

antinuclear antibodies of $\mathrm{IgG}$ class $\left(\mathrm{r}_{\mathrm{s}}=0 \cdot 19, \mathrm{p}=\right.$ $0 \cdot 48$ ). This lack of correlation was further confirmed by comparing titres of virus specific haemolysin antibody in sera with and without antinuclear antibodies $(p=>0 \cdot 10)$. Significant correlations were not found between virus specific haemolysin antibody and serum aspartate aminotransferase and alanine aminotransferase values $\left(r_{s}=0 \cdot 18, p=0.5\right.$; $\left.r_{s}=-0.01, p=0.96\right)$ and total immunoglobulin values $\left(r_{s}=0.23, p=0.44\right)$.

\section{SERUM ABSORPTION}

Absorption of four sera from patients with chronic active hepatitis with smooth muscle tissue prepared from human myometrium either removed completely or reduced the titres of smooth muscle antibody, antinuclear antibodies, and antimitochondrial antibodies of both IgG and IgM classes, but the titres of the virus specific IgG antibodies against haemolysin (unfixed) and haemagglutinin including nucleocapsid (acetone fixed) were not affected.

\section{Discussion}

Increased antibody titres to the envelope antigen haemagglutinin and the internal antigen nucleocapsid of measles virus have been shown previously in the sera of patients with chronic active hepatitis, using haemagglutination inhibition and complement fixation tests. In this study we have shown raised levels of antibodies not only to haemagglutinin but also to the second envelope antigen haemolysin. The antibody titres to haemolysin antigen were found to be higher than antibodies to haemagglutinin by both fluorescence antibody and functional tests, and the significant correlation between these two methods supports our observations. Similar increased titres to measles haemolysin have been reported in patients with subacute sclerosing panencephalitis, multiple sclerosis, and rheumatoid arthritis..$^{16-18}$

Our findings of the incidence of autoantibodies in sera of patients with chronic active hepatitis agree with previous reports. ${ }^{8-10}$ Although the incidence of smooth muscle antibody of IgG class and smooth muscle antibody of IgM class was significantly higher in patients with chronic active hepatitis, by far the highest incidence with high titres was observed in smooth muscle antibody of IgG class, which is accepted as a useful autoantibody marker in patients with chronic active hepatitis. ${ }^{8-10}$ The significant correlation observed between smooth muscle antibody of both IgG and IgM classes with virus specific haemolysin antibody is interesting because in patients with chronic active hepatitis smooth muscle antibody of IgG class shows actin specificity, ${ }^{25}$ and it has also been shown that actin is incorporated into measles virion. ${ }^{13}$ In contrast, smooth muscle antibody of IgM class reacts with cellular intermediate filaments. ${ }^{25}$ The absorption of the sera with smooth muscle tissue prepared from human myometrium did not affect the titres of the virus specific haemolysin or haemagglutinin antibodies but it either reduced or completely removed the smooth muscle antibody of IgG class. These results are not surprising because the smooth muscle used for absorption was a crude preparation that contained all the contractile proteins. ${ }^{26}$ Therefore, if there were restricted but common antigenic determinants shared by measles virus and actin of smooth muscle tissue this absorption would not be effective.

It has been reported recently that monoclonal antibodies against the protein of intermediate filaments of human cells cross react with phosphoprotein of both measles virus and herpes simplex virus. In contrast, monoclonal antibodies against measles virus phosphoprotein did not react with the phosphoprotein of herpes simplex virus and vice versa, indicating recognition by monoclonal antibodies of different antigenic determinants on intermediate filaments. ${ }^{27}$ Further studies with monoclonal antibodies to different antigenic determinants of actin will help to elucidate the correlation observed between smooth muscle antibody of IgG class and haemolysin antibodies specific for measles virus in patients with chronic active hepatitis.

The incidence of antinuclear antibodies of $\mathrm{IgG}$ class was higher in the patients with chronic active hepatitis compared with the control group, but there was no significant correlation between virus specific haemolysin antibody and antinuclear antibodies of 
IgG class, contrary to the observations reported by other workers. ${ }^{46}$ This difference may have been due to the fact that in other studies the complement fixation test was used to measure antibodies specific for measles virus, whereas in our investigation we examined the correlation between envelope haemolysin antigen and antinuclear antibodies of IgG class. It is also important to emphasise that the use of a single method-namely, immunofluorescence-for assay of both measles virus specific antibodies and autoantibodies and their subsequent correlation has an added advantage. Antimitochondrial antibodies, which are considered to be a valuable autoantibody marker in patients with primary biliary cirrhosis but not in those with chronic active hepatitis, ${ }^{8-10}$ were detected in only a few patients.

The implications of raised levels of antibodies against measles virus envelope antigens and of autoantibodies in patients with chronic active hepatitis are unclear. A role for measles virus in the pathogenesis of chronic active hepatitis has been postulated, ${ }^{35-7}$ but so far there is no convincing evidence for the persistence of measles virus antigens or measles virus genome in patients with chronic active hepatitis, nor is there evidence of reinfection in these patients. Similar increased titres of haemolysin inhibition and haemagglutination inhibition antibodies specific for measles virus have also been found in other diseases of unknown aetiology such as multiple sclerosis, rheumatoid arthritis, and systemic lupus erythematosus ${ }^{1828} 29$ and probably reflect defects in immunoregulatory mechanisms. For instance, lack of suppressor T lymphocyte function has been reported in all these diseases ${ }^{30-32}$ and also in chronic active hepatitis. ${ }^{33}$ In view of the fluctuations in titres of both measles virus antibodies and autoantibodies in duplicate sera, further comparative studies on sequential samples from patients with chronic active hepatitis of virus specific antibodies and the factors that help regulate the immune system would be of value.

We thank Dr M McClelland of the Northern Ireland Blood Transfusion Service for providing blood specimens from healthy donors and Mr RG Woods for preparing photographic prints.

\section{References}

' Closs O, Haukenes G, Gjone E, Blomhoff JP. Raised antibody titres in chronic liver disease. Lancet 1971 ;ii: 1202-3.

${ }^{2}$ Triger DR, MacCallum FO, Kurtz JB, Wright R. Raised antibody titres to measles and rubella viruses in chronic active hepatitis. Lancet 1972; i:665-7.

${ }^{3}$ Laitinen O, Vesikari T. Chronic hepatitis with very high rubella and measles virus antibody titres. Lancet $1972 ; \mathrm{ii}: 1141$.

4 Triger DR, Kurtz JB, Wright R. Viral antibodies and autoantibodies in chronic liver disease. Gut 1974; 15:94-8.

${ }^{5}$ Christie KE, Haukenes G. Measles virus specific precipitins in sera from patients with chronic active hepatitis. Scand J Infect Dis 1979;11:99-106.

- Crimmins FB, Adams D, Ross M, Ash G, Thomas HC, Sherlock S. Viral antibody titres in $\mathrm{HBs}$ antigen-positive and -negative chronic hepatitis. Scand J Gastroenterol 1980;15:107-12.

${ }^{7}$ Myren J, Berild D, Orstavik I, Serck Hanssen A. Virus antibodies in the serum of patients with liver disease. Scand $J$ Gastroenterol 1982;17:5-9.

${ }^{8}$ Holborow EJ. Immunological aspects of viral hepatitis. $\mathrm{Br} \mathrm{Med}$ Bull 1972;28:142-4.

' Doniach D. Autoimmune aspects of liver disease. Br Med Bull 1972; 28: 145-8.

${ }^{10}$ Wright R. Immunology of gastrointestinal and liver disease. In: Turk J, ed. Current topics in immunology series. Vol 8. London: Edward Arnold, 1977:93-109.

"Waterson AP. Measles virus. Archiv für die gesamte virusforschung 1960;16:57-80.

12 Norrby E, Hammarskjold B. Structural components of measles virus. Microbios 1972;5:17-29.

${ }^{13}$ Tyrrell DLJ, Norrby E. Structural polypeptide of measles virus. $J$ Gen Virol 1978;39:219-29.

${ }^{14}$ Ehrnst A, Weiner LP, Norrby E. Fluctuations and distribution of measles virus antigens in chronically infected cells. Nature 1974; 248:691-3.

is Fraser KB, Gharpure M, Shirodaria PV, Armstrong MA, Moore A, Dermott E. Distribution and relationships of antigens of measles virus membrane complex in the infected cell and the nature of the haemolysin antigen. In: Mahy BWJ, Barry RD, eds. Negative strand viruses and the host cell. London: Academic Press, 1978:771-80.

${ }^{16}$ Norrby E, Gollmar Y. Appearance and persistence of antibodies against different virus components after regular measles infections. Infect Immun 1972;6:240-7.

"Salmi AA, Norrby E, Panelius M. Identification of different measles virus-specific antibodies in serum and cerebrospinal fluid from patients with subacute sclerosing panencephalitis and multiple sclerosis. Infect Immun 1972;6:248-54.

18 Shirodaria PV, Fraser KB, Armstrong M, Roberts SD. Measles virus-specific antibodies and immunoglobulin $\mathbf{M}$ antiglobulin in sera from multiple sclerosis and rheumatoid arthritis patients. Infect Immun 1979;25:408-16.

14 Armstrong MA, Fraser KB, Shirodaria PV. The sensitivity of measles virus haemolysin to acetone and the preparation of mono-specific human anti-haemolysin by absorption. J Gen Virol 1979; 44:541-3.

${ }^{20}$ Norrby E, Enders-Ruckle G, ter Meulen V. Differences in the appearance of antibodies to structural components of measles virus after immunization with inactivated and live virus. $J$ Infect Dis 1975; 132:262-9.

${ }^{21}$ Leevy CM, Popper H, Sherlock S. Diseases of the liver and biliary tract: standardization of nomenclature, diagnostic criteria and diagnostic methodology. Proceeding No 22. Washington DC: US Government Printing Office, 1976:9-11 (DHEW Publication No 76-725.)

${ }^{22}$ International group. Acute and chronic hepatitis revisited. Lancet 1977;ii:914-9.

${ }^{23}$ Shirodaria PV, Dermott E, Gould EA. Some characteristics of salt-dependent haemagglutinating measles viruses. J Gen Virol 1976;33:107-15.

24 Fraser KB, Shirodaria PV, Haire M. Jejunal biopsy in multiple sclerosis. In: Behan PO, Rose FC, eds. Progress in neurological research. London: Pitman Medical, 1979:73-8.

${ }^{25}$ McMillan SA, Haire M. The specificity of IgG- and IgM-class smooth muscle antibody in the sera of patients with multiple sclerosis and active chronic hepatitis. Clin Immunol Immunopathol 1979;14:256-63. 
${ }^{26}$ Toh BH. Smooth muscle autoantibodies and autoantigens. Clin Exp Immunol 1979;38:621-8.

${ }^{27}$ Funjinami RS, Oldstone MBA, Wroblewska Z, Frankel ME, Koprowski H. Molecular mimicry in virus infection: crossreaction of measles virus phosphoprotein or of herpes simplex virus protein with human intermediate filaments. Proc Nat Acad Sci USA 1983;80:2346-50.

${ }^{28}$ Haire M. Significance of virus antibodies in multiple sclerosis. $\mathbf{B r}$ Med Bull 1977;33:40-4.

${ }^{24}$ Kalliomaki JL, Halonen P, Salmi A. Virus antibodies in serum and synovial fluid of patients with rheumatoid arthritis and other connective tissue disease. Ann Rheum Dis 1975;34:437.

${ }^{30}$ Antel JP, Arnason BGW, Medof ME. Suppressor cell function in multiple sclerosis: correlation with clinical disease activity. Ann Neurol 1979; 5:338-42.

${ }^{31}$ Egeland T, Lea T, Mellbye OJ. T-cell immunoregulatory func- tions in rheumatoid arthritis patients. Scand J Immunol 1983; 18:355-62.

${ }^{32}$ Sakane T, Kotani H, Takada S, Murakawa Y, Ueda Y. A defect in the suppressor circuits among OKT $4^{+}$cell populations in patients with systemic lupus erythematosus occurs independently of a defect in the $\mathrm{OKT}^{+}$suppressor $\mathrm{T}$ cell function. $J$ Immunol 1983;131:753-61.

${ }^{33}$ Alexander GJM, Nouri-Aria KT, Eddleston ALWF, Williams R. Contrasting relations between suppressor-cell function and suppressor-cell number in chronic liver disease. Lancet 1983;i:1291-3.

Requests for reprints to: Dr PV Shirodaria, Department of Microbiology and Immunobiology, The Queen's University of Belfast, Grosvenor Road, Belfast BT12 6BN, Northern Ireland 